\title{
Análisis de una secuencia de Salut les cubains (Agnès Varda, 1963): música y filmación de fotografías
}

\section{Salut les cubains (Agnès Varda, 1963) filmeko sekuentzia baten analisia: musika eta argazkien filmaketa}

\section{Analysis of a sequence of Salut les cubains (Agnès Varda, 1963): music and the shooting of photographs}

\section{Jorge Oter González ${ }^{1}$}

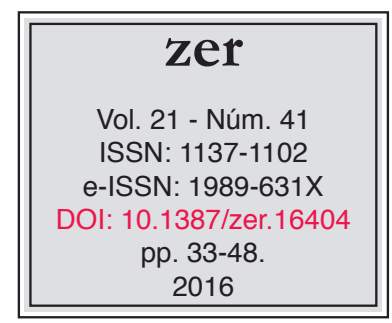

Recibido el 2 de febrero de 2016, aceptado el 16 de mayo de 2016.

\section{Resumen}

A las características y condicionantes propios de las películas que trabajan sobre la filmación de fotografías, Salut les cubains (Agnès Varda, 1963) incorpora, en varias ocasiones de forma enfática, una determinada relación con la música. El análisis pormenorizado de una de las secuencias en que se produce ese contacto querrá reparar en el funcionamiento de dicha secuencia, mostrar su estructura interna, ordenar las diferentes formas de relación entre las imágenes y el sonido que en ella se dan o valorar su relación con un referente a partir de las decisiones tomadas.

Palabras clave: cine, fotografía, documental, música, análisis textual.

\section{Laburpena}

Argazkien filmaketari buruzko filmek berezko ezaugarri eta baldintza batzuk izan ohi dituzte; bada, Salut les cubains (Agnès Varda, 1963) filmak, ezaugarri horiez gain, musikarekiko harreman jakin bat sartzen du hainbat unetan, modu enfatiko batean. Harreman hori gertatzen den sekuentzietako bat zehatz-mehatz aztertzeko, sekuentzia horren funtzionamenduari erreparatu behar zaio, haren barne-egitura erakutsi behar da, irudien eta irudi horietan entzuten den soinuaren arteko harreman motak antolatu edo hartutako erabakietatik ateratako erreferente batekin duen harremana baloratu.

Gako-hitzak: Zinema, argazkilaritza, dokumentala, musika, testu-analisia.

\footnotetext{
Escuela Superior Politécnica Tecnocampus, joter@tecnocampus.cat
} 


\begin{abstract}
In several moments of its footage, Salut les cubains (Agnès Varda, 1963) adds to the particularities and characteristic limitations of the films that film photographs another connection, specifically with music. Close analysis of one of the sequences in which this connection takes place is accomplished in order to examine its functioning, reveal its structure, classify the different relations between image and sound along the sequence, and reconsider its relation to a referent bearing in mind the different choices in the film.
\end{abstract}

Keywords: cinema, photography, documentary, music, textual analysis. 


\section{Introducción}

Agnés Varda comenzó como fotógrafa antes que cineasta, pero con La Pointe-courte (1954) decidió adentrarse en el cine ${ }^{2}$. En su filmografía, la relación con la fotografía ha ido reapareciendo de diferentes maneras. Entre los casos más inmediatos se cuenta Ulysse (1982), que narra el retorno de la cineasta sobre su fotografía homónima de 1954, reencontrándose con los protagonistas de aquélla. En Une minute pour une image (1983), serie de micro episodios emitida por la televisión, un observador (la cineasta, un personaje popular o un anónimo) comentaban por un breve lapso de tiempo una fotografía, sobre la que se operaban diferentes intervenciones visuales. En Ydessa, les ours et etc. (2004) la atención se centra en el conjunto fotográfico reunido por una coleccionista. En cualquier caso, las relaciones interartísticas del cine de Varda no se limitan a la fotografía y tienen que ver con la pintura (los murales), como en Murs, murs (1981), o, como veremos, con la música.

Por otra parte, la autora ha trabajado en su filmografía con diferentes duraciones, moviéndose desde sus inicios con soltura entre el cortometraje y el largometraje ${ }^{3}$. Salut les cubains (1963) es un cortometraje de Agnès Varda relacionado con la fotografía, en este caso en un sentido material: Varda viajó a Cuba, junto con otros cineastas franceses, cuatro años después de la revolución; su estancia se prolongó entre diciembre de 1962 y enero de 1963; debido a limitaciones económicas, no viajó con un equipo de cine, sino que planeó una película realizada a partir de la filmación de las fotografías tomadas durante el viaje. Varda volvió con unas 2.500 fotografías, de las cuales, según se ha señalado, 1.800 habrían entrado a formar parte del film ${ }^{4-5}$.

Salut les cubains es una película, en su consideración más característica, constituida por una banda de imagen consistente en la presentación de fotografías tomadas en Cuba y por diferentes elementos de audio: las voces en off de Michel Piccoli y Agnès Varda (esta última no reflejada en los títulos de crédito) ${ }^{6}$; una música profusa, mayoritariamente cubana ${ }^{7}$; diferentes ruidos. Y decimos en su consideración más

\footnotetext{
2 Sobre los inicios como fotógrafa de Varda, puede consultarse: Bastide, 1991. Varda ha descrito como misteriosas las razones que le llevaron a su debut, sin haber tenido apenas contacto previo con el cine (Fieschi, 1965: 45).

3 Varda mantendría una relación íntima con la duración del film, como intuición que tendría como referencia desde las fases iniciales (Varda, 1990: 95). Su producción cortometrajística ha sido tan profusa que ha sido recogida en un doble DVD: Tous courts (Ciné-Tamaris, 2007).

${ }^{4}$ La cifra ha sido exagerada. Bernard Bastide ha señalado cómo la cifra de 4.000 fotografías tomadas en Cuba habría sido exagerada por la propia Varda (Bastide, 1994: 237) y, en una entrevista de Gerald Peary de 1977, puede incluso encontrarse la indicación de que en realidad se tomaron unas 6.000 fotografías (Kline, 2014: 90). Sylvain Dreyer precisa que fueron 1.500 las que «fueron seleccionadas y filmadas en la truca». (2009: 25)

5 Ydessa, les ours et etc., Ulysse y Salut les cubains fueron reunidas en Cinévardaphoto (2004).

${ }^{6}$ Entre ambas voces se lleva a cabo un particular juego, según la asignación a cada una de ellas de una cierta personalidad. (Véanse, por ejemplo, la observación detallada de Inma Merino (2012: 190-196) o las menciones de Dreyer (2009: 29-30))

7 Algunas filmografías colocan a Michel Legrand en el apartado de «música» (como en Invernici, 2010: 117 o Kline, 2014: xxviii). Los títulos de crédito de Salut les cubains no hacen mención a este componente. Michel Legrand fue, con anterioridad a este film, autor de la música del corto Les fiancés du Pont Mac Donald (1961) o de Cleo de cinco a siete (Cléo de 5 à 7, 1961), ambos de Varda. Pero en Salut les cubains su participación es secundaria y parecería ligarse al empleo en el film de
} 
característica porque la película presenta al comienzo una suerte de introducción con imágenes en movimiento, al final de algunos de cuyos planos se realizan congelados de imagen sobre los que se impresionan los títulos de crédito ${ }^{8}$.

Los efectos de congelación anticipan la inmovilidad posterior de las fotografías. Al mismo tiempo, ya desde el comienzo se plantea la importancia del componente sonoro de la película, con la música cubana que acompaña con gran protagonismo a las imágenes. Éstas están fechadas: Michel Piccoli señala que se trata de «París, Saint-Germain-des-Prés, junio de 1963»; tras un fundido a negro y la subsiguiente salida de él, el film pasa, para el resto de su metraje, a las imágenes basadas en las fotografías, y es ahora Varda quien lo fecha: «Cuba, enero de 1963». Como bien se ha señalado, el intervalo de tiempo que se comunica es el del tiempo de procesado de los materiales y construcción del film (Dreyer, 2009: 26).

Asimismo, desde el comienzo se plantea la que será una característica constante de la película, importante en la proporción en la que el sonido es en ella importante: la falta de correspondencia intrínseca en la relación que mantienen la imagen y el sonido. Las fotografías a partir de las cuales se construyen las imágenes de Salut les cubains se remiten a la puntualidad del instante capturado $\mathrm{y}$, dadas las características de su soporte, sin duración, no pueden ligar ese momento a un sonido ${ }^{9}$. Ello no impide las relaciones cinematográficas con el sonido, gracias a la duración de los planos del nuevo medio en que se instalan las fotografías.

\section{La secuencia de Benny Moré}

Salut les cubains, que fue recibida como una forma de «propaganda sutil y amistosa» ${ }^{10}$, deposita el grueso de su atención sobre las capas populares de la Cuba postrevolucionaria, realizando un recorrido variado y aparentemente aleatorio por la realidad del país ${ }^{11}$. La música sirve como medio para ese acercamiento, y cobra progresiva importancia a lo largo del metraje y conduce por completo la película en su segunda mitad ${ }^{12}$. Si la película se abre con la música del prólogo en las calles de París, ésta se asienta en el film con la entrada en escena del cantante Benny Moré, que protagoniza una secuencia de baile que puede señalarse como la primera propuesta de animación con entidad del film, prolongada y consistente y vinculada al plus de movimiento que el baile

un tema por él compuesto para la banda sonora de América insólita (L'Amérique insolite, François Reichenbach, 1960).

8 La propia Varda ha señalado cómo estos congelados ayudan a reconocer en ese prólogo a William Klein, Joris Ivens, Alain Resnais, Jacques Demy y a ella misma (Grar, 2010: 136).

9 Jan-Christopher Horak se habría detenido en esta circunstancia en relación a otra película realizada a partir de la filmación de fotografías. Para La jetée (Chris Marker, 1962), ha señalado que, "sin la capacidad de moverse, los actores son incapaces de hablar; sólo pueden ser citados por el narrador del film” (1997: 45).

${ }^{10}$ En expresión del embajador cubano en Bélgica, Gustavo Arcos, en una carta a Varda de enero de 1964 (recogida por Bastide: ver Dreyer, 2009: 27).

${ }^{11}$ Merino, a partir de Dreyer: «Alejándose de la forma demostrativa que caracteriza al cine militante, las secuencias se encadenan siguiendo la (no) lógica del coq-à-l’âne, es decir, pasando de una cosa a la otra a través de los juegos de palabras y de las asociaciones libres que forman parte del universo Varda» (2012: 190)

12 Varda ha señalado cómo habría querido explicar los orígenes de la música cubana (ver Varda, 1994: 237; también señalado en el propio film). 
supone sobre la movilidad cotidiana; posteriormente, en el ecuador del film se lleva a cabo una nueva animación, en la secuencia de la recolección de las cañas de azúcar, que abre la veda para posteriores animaciones y escenas musicales, hasta el cierre del film con un baile final, en la calle, con anfitriones cubanas y miembros del equipo.

A Benny Moré se le proporciona una presentación destacada: «Por último, he aquí El Rey. O al menos aquél a quien la gente de La Habana llama "El rey del ritmo" y, a veces, "El bárbaro"»13 , mientras brinda y saluda a la cámara (en una frase fotográfica de cuatro imágenes; más tarde nos referiremos a otras frases en la secuencia). La presentación de un personaje destacado en la película da paso a una secuencia destacada: gozando de una clara unidad, con su propio prólogo (esta presentación enfática del personaje) y su epílogo tras el baile, concluido con un fundido a negro (el epílogo sirve para despedir desde el film, por medio de la voz de Varda, a un Moré que falleció en febrero de 1963), la secuencia se instala como un bloque delimitado dentro del film. Además, queda asociada a unas coordenadas espacio-temporales muy concretas, las del restaurante en que se produce el encuentro, en una película que hasta entonces ha ido pasando de una cosa a otra (incluso en cuanto al origen de los materiales: de las fotografías tomadas por la producción a la utilización de imágenes de otras procedencias, como de la prensa) ${ }^{14}$.

\section{Estructuras en la secuencia}

Si las imágenes se vinculan a la secuencia como a una unidad definida según las estrategias señaladas (establecimiento de unas coordenadas, delimitación por medio de un prólogo y un epílogo, uso de la música), amén de otras como la relación con un mismo personaje o la reaparición de un número limitado de figuras (del atuendo de Moré a las características y la textura del espacio en que la secuencia tiene lugar), la lógica del movimiento del baile no puede sino hacer énfasis en la secuencialidad de las imágenes, esto es, en la sucesión y combinación de las mismas: si en la producción se ha obtenido un conjunto de imágenes fotográficas de la interpretación del baile por parte del cantante, en la postproducción éstas se relacionan para transmitir una idea de aquel baile.

Esto sucede en la secuencia del baile de Benny Moré, como también en otros momentos de Salut les cubains. El espectador se enfrenta a una intervención segunda: en primer lugar, las fotografías hicieron un registro del acontecimiento; posteriormente, se instalan en el engranaje cinematográfico (son registradas en la truca). El espectador es espectador de estas últimas imágenes, que proponen un discurso muy elaborado en torno a aquel acontecimiento inicial en el restaurante. A diferencia de

\footnotetext{
${ }^{13}$ Benny Moré pasaría por ser uno de los músicos más importantes de la Historia de la música cubana. Inma Merino ha señalado cómo la aparición en el film del presidente de la República Osvaldo Dorticós, previa a la de Moré, parecería estar pensada para dar pie a la presentación subsiguiente de «El Rey» (2012: 194).

${ }^{14}$ Grar ha reparado en el uso de imágenes de prensa. En referencia a una de ellas, habiendo accedido a los materiales que dieron lugar al film: «En una de las cajas, encontramos una fotografía en papel de revista recortada por el contorno de su protagonista. Encontramos, en efecto, esta fotografía en el film, según un tratamiento indiferenciado de las otras. Es la única foto proveniente de un soporte periodístico que se encontró en las cajas que contenían las fotos. Esto nos permite justificar la mezcla de diversas fuentes fotográficas y su tratamiento indiferenciado. Agnès Varda refotografía las fotos con su Leica, lo que ofrece un resultado estético similar para todas las fotos, sea cual sea su origen.» (2010: 135)
} 
las fotografías, el cine dispone como medio de la posibilidad de construir una duración concreta, y hace uso de ella para sustituirlas y generar una idea de movimiento, en una combinación consciente y en diálogo directo con la música, según las estructuras que hemos reconocido.

Encontramos, en esta secuencia, distintos momentos. Si los extremos se encuentran definidos por la presencia de un prólogo y la de un epílogo, la secuencia cuenta con una parte central de mayor extensión que puede ser segmentada en unidades más pequeñas. Esta parte central, el cuerpo de la secuencia, es precisamente la parte en conjunción con la cual suena la música que Moré baila y canta (no hay música en el prólogo ni en el epílogo). De forma general, esta parte central y musical de la secuencia puede dividirse en, por un lado, un segmento de arranque y, a partir de ahí, en toda una sucesión de segmentos que podemos distinguir como A y B, formalmente diferenciados y ligados de manera notablemente constante a lo que sucede en la banda sonora (Ver Tabla 1).

El segmento de arranque está compuesto por tres imágenes (fotografías, como en la secuencia al completo) ligadas al arranque del tema Caricias cubanas (1957), interpretado por Benny Moré. Tras un silencio, las imágenes se ponen en marcha a la vez que la música, y nos encontramos entonces con un primer conjunto de imágenes (tipo A) ligadas a una parte del tema en la que destacan las voces de los coristas: visualmente, en plano general, las imágenes describen un mismo punto de vista en un restaurante; Benny Moré se desplaza en profundidad, desde el fondo hacia la cámara, interpretando el baile. La sensación de profundidad se encuentra enfatizada por la disposición a los lados de dos carros con vasos y vajillas, que definen un pasillo central al que el cantante ciñe su recorrido en el, por lo demás, amplio espacio del comedor. El segmento concluye con Moré muy cercano a la cámara. Esta imagen (la decimonovena en el segmento o imagen 1.19 en nuestro découpage; ver Figura 1) reaparecerá al final de Salut les cubains, dentro de una secuencia también musical y de resumen de diferentes situaciones previas; la imagen también reaparece en otros segmentos de la parte central de la secuencia (siempre del tipo A: números 16 y 18; ver Tabla 1).

Figura 1. Ejemplo de punto de vista de los grupos de imágenes de tipo A (imagen 1.19).

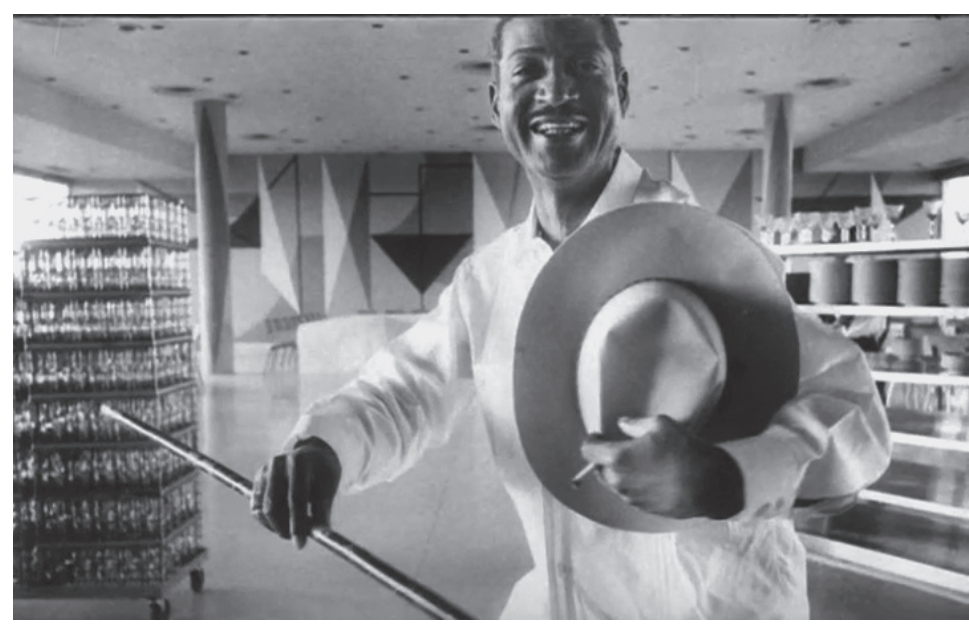


Única vez en toda la secuencia, a un segmento A le sigue otro segmento A. Todavía sentándose las bases del sistema que se seguirá en la misma, el cantante reinicia (salta, de hecho, al punto de inicio en el salón; y salta a la misma fotografía, que se repite) su baile en profundidad y de acercamiento a la cámara. Por lo tanto, en la banda de audio también se reinterpretan los coros, volviendo sobre las mismas frases. Pero en el momento en que Moré comienza su solo vocal se plantea, en cambio, otro tipo de imágenes, caracterizadas por ser primeros planos del artista que atienden a su gestualidad facial y bucal (tipo B). Ésta es la lógica que sigue la secuencia en adelante, pasando de modelos A a modelos B, etc., sin excepción. La duración de los mismos puede variar. La primera incursión en un modelo B, o modelo de primeros planos, presenta muchas más imágenes que cualquiera de los B siguientes, pero también son particularmente cuantiosos los mencionados primeros dos segmentos de tipo A, que excepcionalmente aparecen seguidos (en cualquier caso, el segmento 3 viene a duplicar en imágenes a los segmentos 1 y 2 , según nuestro découpage). A partir de ahí, la sucesión es más regular y breve en cuanto a su presencia en pantalla ${ }^{15}$.

Figura 2. Ejemplo de punto de vista de los grupos de imágenes de tipo B (primeros planos) (imagen 5.1).

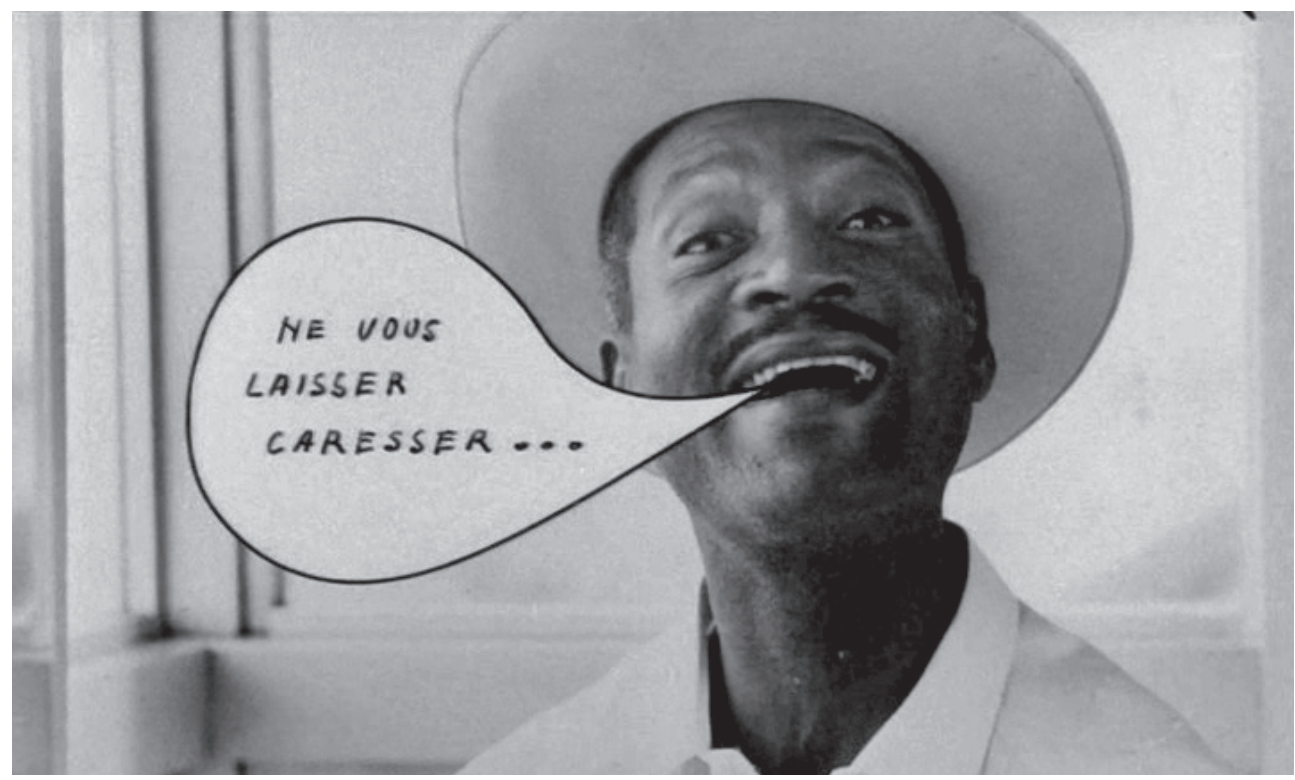

Por lo demás, reconocemos ciertas particularidades en esos bloques de primeros planos que coinciden con los solos cantados de Benny Moré. En una primera ocasión, su relación es de sustitución, por encadenado casi todas las veces o por corte, y las tomas asumen en apariencia el mismo encuadre sobre el rostro del artista, del mismo

\footnotetext{
${ }^{15}$ Un trabajo directo sobre el celuloide permitiría cuantificar en fotogramas la presencia en pantalla de cada imagen, teniendo en cuenta que su característico origen fotográfico permite aprehenderlas como unidades muy definidas. Precisamente, ese examen permitiría trabajar en la definición y comprensión detallada de los momentos más combinatorios, como la serie de encadenados del segmento 3 (ver Tabla 2).
} 
modo que las tomas del tipo A ofrecían siempre un mismo encuadre del salón ${ }^{16}$. A lo largo de la secuencia se dan, por lo demás, variaciones sobre el tratamiento de los primeros planos: la siguiente incursión, tras un nuevo baile por el salón, presenta tan sólo dos imágenes de primer plano; de la boca de Moré surge un bocadillo como de cómic: «¡No te dejes acariciar la cara.../...más que por las cubanas!» (segmento 5, tipo Bc; ver Tabla 1, ver Figura 2). Posteriormente habrá una nueva ocasión, precisamente en la última aparición de primeros planos dentro de esta parte central y musical de la secuencia, en que se volverán a utilizar bocadillos sobre dos imágenes (segmento 17; siempre, en cada uno de los casos de estas cuatro imágenes, se trata la misma fotografía de base $)^{17}$.

No obstante, el caso más frecuente consiste en la presentación de cuatro imágenes de primeros planos, separadas por corte, sobre la primera de las cuales se realiza un zoom in (tipo $\mathrm{Bb}$ ). Como en todos los casos de primeros planos, musicalmente se trata de momentos de solo vocal del cantante.

Tabla 1. Resumen de découpage.

\begin{tabular}{|c|c|c|c|c|c|}
\hline $\mathbf{N}^{\circ}$ segmento & Tipo & Música & $\mathbf{N}^{\circ}$ segmento & Tipo & Música \\
\hline & Prólogo & $\begin{array}{c}\times \text { off Piccoli } \& \\
\text { Varda }\end{array}$ & 10 & $\mathrm{~A}$ & $\checkmark$ coro \\
\hline 0 & Arranque & $\checkmark$ música & 11 & $\mathrm{Bb}$ & $\checkmark$ solo \\
\hline 1 & $\mathrm{~A}$ & $\checkmark$ coro & 12 & $\mathrm{~A}$ & $\checkmark$ coro \\
\hline 2 & $\mathrm{~A}$ & $\checkmark$ coro & 13 & $\mathrm{Bb}$ & $\checkmark$ solo \\
\hline 3 & $\mathrm{~B}$ & $\checkmark$ solo & 14 & $\mathrm{~A}$ & $\checkmark$ coro \\
\hline 4 & $\mathrm{~A}$ & $\checkmark$ música & 15 & $\mathrm{Bb}$ & $\checkmark$ solo \\
\hline 5 & $\mathrm{Bc}$ & $\checkmark$ solo & 16 & $\mathrm{~A}$ & $\checkmark$ coro \\
\hline 6 & $\mathrm{~A}$ & $\checkmark$ coro & 17 & $\mathrm{Bc}$ & $\checkmark$ solo \\
\hline 7 & $\mathrm{Bb}$ & $\checkmark$ solo & 18 & $\mathrm{~A}$ & $\checkmark$ música \\
\hline 8 & $\mathrm{~A}$ & $\checkmark$ coro & & Epílogo & $\times$ off Varda \\
\hline 9 & $\mathrm{Bb}$ & $\checkmark$ solo & & & \\
\hline
\end{tabular}

Fuente: Elaboración propia.

En resumen, dentro de esta secuencia de Salut les cubains, se han podido localizar diferentes partes que se han distinguido como prólogo, parte central y epílogo. Dentro de dicha parte central se han reconocido a su vez diferentes segmentos: un arranque y una sucesión de imágenes estéticamente diferenciables reunidas en segmentos

\footnotetext{
${ }^{16}$ En este caso, más que de una circunstancia efectiva, se trata de una intención estética: el tratamiento del rostro es homogéneo para todas las imágenes, pero el examen minucioso de las características del espacio circundante indicaría, con probabilidad, que la ubicación del referente no es siempre la misma.

${ }^{17}$ El análisis puede desarrollarse: en las primeras imágenes de cada uno de los segmentos (seg. 5 y 17), predomina el verbo «acariciar» (siempre como última palabra), mientras que en las segundas lo hace el sustantivo «cubana» (siempre como última palabra); la primera imagen presenta 3 líneas de texto (seg. 5) y luego 2 (seg. 17), la segunda 3 en ambas ocasiones (seg. 5 y 17), cerrando en ambas con el signo de exclamación (escrito tan sólo al final, en lengua francesa).
} 
que reaparecen con variaciones (distinguidos como A y B). Pero aún dentro de los segmentos podría profundizarse en las diferentes dinámicas planteadas. Sirva como ejemplo, dentro de la primera aparición de primeros planos musicales (seg. 3, tipo B), el reconocimiento de diferentes frases visuales, de distinta duración, asociadas a frases pronunciadas por el cantante, es decir, a la letra de la canción:

Tabla 2. Relación letra-imágenes en el segmento 3.

\begin{tabular}{|c|c|c|}
\hline $\mathbf{N}^{0}$ de frase & Letra de Caricias cubanas & $\mathbf{N}^{\mathbf{0}}$ de imágenes \\
\hline 1 & Si son cubanas & 4 imágenes \\
\hline 2 & son más celosas, & 5 imágenes \\
\hline 3 & son más hermosas las de La Habana. & 9 imágenes \\
\hline 4 & Y las indianas & 4 imágenes \\
\hline 5 & de Santa Clara & 4 imágenes \\
\hline 6 & son tan preciosas y no son tan caras & $8+3$ imágenes \\
\hline
\end{tabular}

Fuente: Elaboración propia (letra en Meini, 2003: 105).

No casualmente se llega a este segmento tras un acercamiento muy acusado del cantante a la cámara, después de haber realizado uno de sus bailes a lo largo del pasillo diseñado en el comedor (imagen 2.18): el acercamiento es tan pronunciado que el cantante parece sorprender a la cámara y se muestra desenfocado, mientras el fondo sigue apareciendo nítido. En cuanto a ellas, las frases ofrecen materialmente la idea de una propuesta de intención estética desde la imagen en relación al sonido. En un desarrollo crítico mayor, podría ahondarse en el reconocimiento de esas intenciones, a partir de la duración mayor de las imágenes finales de cada una de las frases o de la designación de determinadas imágenes como imágenes susceptibles de constituir una imagen final, como en este caso la imagen 3.4, que es la imagen final de la primera frase (4 imágenes), pero también de la tercera (9 imágenes), de la cuarta (4 imágenes) y de la quinta (4 imágenes) (ver Figura 3). Pero es que además, es la penúltima imagen de la segunda frase (5 imágenes) y de la sexta frase (en dos movimientos, $8+3$ imágenes), observando también que se repite, a su vez, la imagen final en estas dos frases (que todavía resulta ser la penúltima imagen de la cuarta frase... y la última del prólogo). De este modo, ambas imágenes se relacionan como elementos finales de tres frases del mismo segmento (segunda, cuarta y sexta), es decir, como elementos con posibilidad de finalizar de forma yuxtapuesta una frase. Y el resultado es un acento en el discurso: en las frases 1 a la 6 (ver Tabla 2), los finales con combinación de ambas imágenes responden a un no-sí-no-sí-no-sí.

Es así que en esta secuencia de Salut les cubains se repiten imágenes que pueden tender a ocupar unas determinadas posiciones en las frases en que aparecen, de modo que esas imágenes adquirirían una carga semántica ${ }^{18}$. El montaje tendería

\footnotetext{
${ }^{18}$ Necesariamente, las figuras que aparecen en estas imágenes son apropiadas para expresar unos determinados sentidos (ej. labios abiertos/labios cerrados). El montaje, que les otorga una ubicación y con ello un rol en la secuencia, les añade un determinado componente semántico, como puede ser en este caso su dimensión conclusiva en la frase.
} 
a establecer en estas frases algunas asociaciones entre imágenes, que se ofrecen al reconocimiento del espectador.

Figura 3: Imagen 3.4 (imagen final de frase).

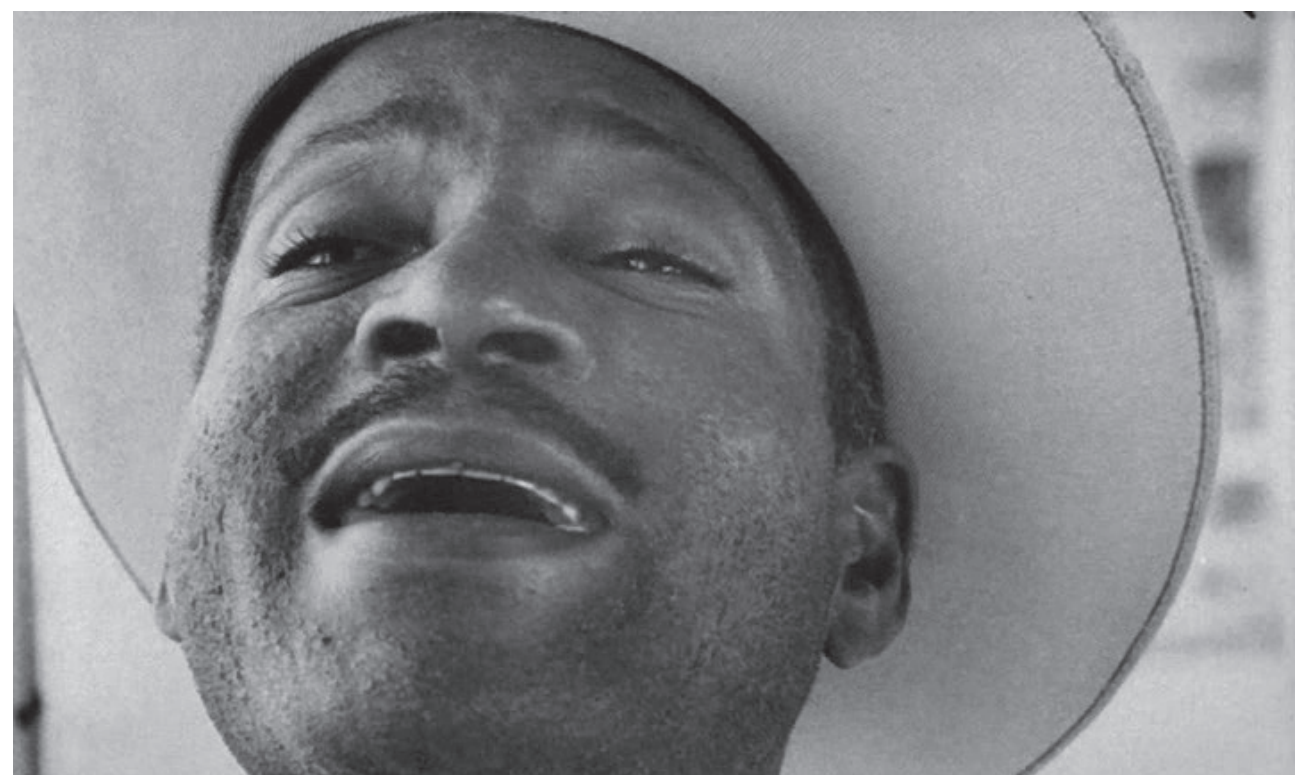

\section{Relaciones entre imágenes}

La organización del material fotográfico en la película conlleva diferentes relaciones. En el plano material más inmediato, estas imágenes fotográficas se relacionan entre sí de dos maneras, según opciones básicas de montaje: por corte o por encadenado. Estas imágenes, que por sus características de soporte se ofrecen de entrada separadas (aunque bien pueden organizarse según los principios de una secuencia en, por ejemplo, un contexto expositivo) se incorporan en el cine al discurso de una sola nueva obra. La relación entre las mismas se lleva a cabo en el contex to de la duración cinematográfica y de la necesidad de decidir sobre el modo en que nuevas imágenes ocuparán el espacio del cuadro de imagen.

En relación a la secuencia observada, los grupos de imágenes de tipo A (planos generales del salón comedor) se relacionan por corte, mientras que las de tipo B (primeros planos del cantante) pueden hacerlo por corte o por encadenado. El procedimiento del corte parecería una forma natural al dispositivo cinematográfico: un plano se termina y deja paso inmediato al siguiente. En cierta manera, este sistema repite, a escala de lo visible, el reemplazo invisible que opera en la sustitución de fotogramas que da lugar a la sensación de continuidad de la imagen en pantalla (en vez de fotogramas, ahora pensamos en fotografías); de hecho, cada corte no es sino una alusión a la discontinuidad intrínseca del cine. Por lo demás, según la propuesta formal del film, a partir de fotografías debe darse cuenta del baile realizado por Moré ante la cámara fotográfica y, en realidad, no se trata sólo de representar una movilidad (o quizá 
de producir una sensación de movilidad), sino de representar el plus de movilidad que de por sí supone el baile sobre la movilidad de la vida ${ }^{19}$.

En segundo lugar, la relación entre imágenes se plantea con recurso al procedimiento del encadenado. En la secuencia que nos ocupa este mecanismo sólo aparece, en la parte musical de la misma, en imágenes de tipo B (primeros planos). Fuera de ésta también se encadenan las imágenes del epílogo, aunque no ya con la intención de crear un movimiento tanto como un tono en la imagen: recordemos que se trata de las imágenes de despedida del cantante fallecido. La velocidad de sustitución es en este momento mucho menor que en los casos anteriores, es decir, en los casos musicales; tampoco en el prólogo (por corte) hay un trabajo sobre la velocidad de sustitución, que relacionamos con un deseo de generar movilidad ${ }^{20}$.

A diferencia de la relación discontinua que propone el uso del corte, el recurso al encadenado quiere producir una forma de relación entre imágenes que precisamente cubra la separación entre unas y otras. El tercer segmento (ver Tabla 1) de la secuencia de Benny Moré hace un uso profuso del encadenado; de hecho, este segmento ya entra encadenado desde la última de las imágenes del segmento anterior, y encadena todas sus imágenes (recordemos que se trataba de un segmento particularmente largo) salvo las tres últimas, que, introducidas por corte, plantean visualmente una especie de staccato vinculado a la pronunciación vocal del cantante. El resultado es una serie de imágenes ligadas entre sí, efectivamente mezcladas por este procedimiento técnico, que abundan en la aparente proximidad espacio-temporal de la toma de las diferentes imágenes fotográficas, y es así que, gracias al aparente mantenimiento del punto de vista en la toma, se plantea un continuo (el uso del encadenado es tan intensivo que parecería que algunas de las imágenes no se mostrarían en ningún momento de forma íntegra, solas, sin compartir plano con otra imagen).

La relación con la música es clave en Salut les cubains. Como se ha señalado, las imágenes de primeros planos coinciden con los momentos de interpretación individual por parte del cantante. El uso del encadenado, ligado a la diferente presencia de cada imagen en pantalla (habíamos reconocido el uso de diferentes frases en el segmento, con una presencia más prolongada de la última imagen de cada frase, posición para la que algunas imágenes parecían más propicias que otras), ese uso del encadenado está dirigido a la creación de una articulación visual que encaje con la propuesta sonora $^{21}$. En eso no se diferencia de los momentos en que se utiliza el corte; la aportación del encadenado es la de querer recrear una sensación de movilidad

${ }^{19}$ Como si el baile fuese movimiento superpuesto al movimiento del mundo real, en alusión a la concepción de Bazin del color de la pintura, «color superpuesto al color del mundo real» (2004: 226).

${ }^{20}$ El trabajo sobre la representación del movimiento está, en Salut les cubains, intensamente abordado. La velocidad de sustitución y la presencia en pantalla de cada imagen merecerían un examen pormenorizado, que podría dar lugar a una representación esquematizada y visual del peso de los componentes del film (ver nota 14). Notamos, además, que tras el fundido a negro que cierra el epílogo, la primera imagen que aparece en la secuencia siguiente es, extrañamente, un retrato del propio Benny Moré, si bien en la película se presenta como si no hubiese correspondencia (el reconocimiento no es seguro para quien no conoce al cantante, por su gestualidad y su atavío en esta imagen).

21 Ello coincidiría con la afirmación de Varda de que habría montado en primer lugar el sonido y después, en relación a él, las imágenes: «preparé el rodaje en la truca (es decir con una cámara suspendida en vertical sobre las fotografías) habiendo ya pasado el sonido a positivo óptico, a fin de calcular el número de imágenes según el ritmo» (Varda, 1994: 133). 
sin fisuras, representando la integridad del movimiento acontecido ante la cámara, para lo que se apoya en el sonido. Roger Odin ${ }^{22}$ ha señalado: "Estas formas intermedias tienen como característica común restituir el movimiento basándose no ya en el défilement, sino en el montaje" (1981: 154).

Por lo demás, en Salut les cubains las relaciones no se producen sólo entre planos inmediatamente contiguos, sino que la película plantea una multitud de llamadas internas entre diferentes imágenes. En lo que se refiere a la secuencia de Benny Moré, ya se han señalado algunas de las repeticiones de imágenes que se producen sin salir de ella, así como, aún más afuera, la reaparición hacia el final del film de una imagen del cantante dentro de una serie de imágenes que proponen un repaso de diversos momentos del metraje, después de un baile en la calle al son de El cuini tiene bandera (Orquesta Aragón, 1961). Las referencias internas son frecuentes en el film y plantean la reaparición de ciertos personajes, identificados por las voces en off (de Selma Díaz a Armand Gatti, si bien en concreto éstos solamente se muestran y no se nombran en su primera aparición) o simplemente mostrados visualmente (como algunos anónimos), pero que entonces se nos ofrecen marcados por el contacto previo. Estas reapariciones pueden producirse en la forma de repeticiones de imágenes o mediante imágenes nuevas. En cualquier caso, suponen un trabajo sobre la complejidad semántica del film, así como sobre la importancia del lugar de aparición de la imagen (y su duración en plano, entendiendo la duración como un aspecto de su ubicación), con un ejemplo elocuente en esas imágenes que sirven para cerrar frases en el segmento observado del solo de Benny Moré (seg. 3).

\section{Implicaciones teóricas}

Salut les cubains decide crear un discurso a partir de imágenes fotográficas, lo que determina el aspecto de la película. La elipsis será consustancial a este sistema: según ha señalado Jean-Claude Chirollet en relación a la fotonovela, que guarda importantes relaciones con el sistema secuencial de los films que utilizan fotografías, si el espectador quiere completar las ausencias habrá de hacer uso de la imaginación (1983: 108, 111). En relación a la toma de imágenes, Varda ha señalado que:

"la Leica obligaba a recargar dos veces, es decir que pasaban algunos segundos entre cada disparo. Por tanto, en lugar de reconstituir un movimiento continuo filmando imágenes muy cercanas en el tiempo, no se pudo reconstituir más que una continuidad a trompicones que le da al film el ritmo del chachachá, del bolero, del danzón y del guaguancó” (1994: 133) .

La elipsis condiciona la representatividad indicial de la secuencia. No hay un continuo en la captura de la imagen, como sucedería en el cine, aunque sabemos que el cine no registra todo el desarrollo referencial y, de hecho, puede reconocerse en este intento

\footnotetext{
${ }^{22}$ Encontramos ambos modelos (encadenado y corte) en La jetée, aunque sin una relación con el sonido como la de Salut les cubains. Para Odin, que se fija en su uso en el film de Marker, estas intervenciones se sitúan «entre la representación y la reproducción del movimiento»; logran un grado de acercamiento a la forma de reproducción cinematográfica del movimiento, de ahí que la evoquen, pero «sin llegar a reproducirlo realmente» (1981: 154).
} 
de creación de un movimiento a través del montaje por corte de las fotografías una alusión a la discontinuidad interna cinematográfica. No obstante, por comparación con la forma en que el plano cinematográfico acomete la reproducción del desarrollo del referente, la representación con fotografías se mostrará como un procedimiento incompleto. Pero, en muchos de los momentos de estos films, de Salut les cubains a La jetée (1962) o Colloque de chiens (Raúl Ruiz, 1977), no se persigue siquiera la transmisión de ese continuo; la propuesta estética circula por otros caminos, y se ha de observar que lo hace, en cualquier caso, sin perder su conexión indicial con el mundo, que es la del medio fotográfico que se utiliza como base para crear los films.

La situación adquiere un interés específico cuando esta forma de construcción del discurso pretende producir una impresión mayor de movimiento, y entonces se aproxima al modo de funcionamiento cinematográfico. Es el caso, por ejemplo, de los momentos del baile y canción de Benny Moré en Salut les cubains, que trabajan sobre las variaciones de las figuras de unas imágenes aparentemente tomadas desde un mismo punto de vista, proponiendo así que se trata de imágenes muy próximas espacio-temporalmente. Es decir, son ocasiones en las que se trabaja asimismo en relación a un hipotético continuo referencial, que vendría a trasmitirse según las posibilidades particulares del sistema expresivo escogido. Y, para afianzar la transmisión, en estos casos se hace uso de la música.

La banda musical refuerza la unidad del conjunto fotográfico de la secuencia. La voz en off de Varda nos indica en el film: «Benny Moré canta y baila para nosotros un son montuno, un tipo de ritmo derivado de los cantos campesinos». Se ha señalado cómo, pormenorizadamente, las imágenes atenderían al desarrollo sonoro: los cambios de posturas (tipo A) pretenden acompasarse con las inflexiones musicales; las diferentes expresiones faciales (tipo B) quieren asociarse a las características de la letra, en ocasiones a un nivel silábico. Por lo tanto, se construye una idea de bloque, de unidad visual y sonora con respecto a lo representado. En atención a esa relación, podría pensarse en el caso particular de una película como Horizontes perdidos (Lost Horizon, Frank Capra, 1937): en la reconstrucción de la película se utilizaron imágenes de producción, de plató o imágenes congeladas de otros momentos del film para ocupar los huecos del metraje perdido, pero, en cambio, se pudo disponer del audio completo del film, que sirvió como guía para asignar a esas imágenes una duración materialmente exacta (Gitt, 2001).

El sonido definiría, en la secuencia de Salut les cubains, la correcta representatividad de las imágenes, que de lo contrario quedaría abierta; el sonido determina que las imágenes así relacionadas quieren representar un desarrollo concreto (como puede ser la pronunciación de unos versos a cierto ritmo) que, para producirse, requiere una determinada duración: si sabemos la duración que las imágenes quieren significar, es porque conocemos lo que duran las palabras que las imágenes representan decir. Es así que las imágenes querrían mostrar, por encima del movimiento ausente, habiéndose escogido un sistema ajeno a una posibilidad de reproducción del movimiento original (las elipsis de registro son inherentes a este sistema fotográfico), esas imágenes querrían mostrar su capacidad para representar el acontecimiento original. En relación al baile originalmente realizado por el cantante, a través de una construcción concreta de imágenes y sonidos, el espectador accede a un sentido de aquel baile. 
En cualquier caso, sabemos que la correspondencia de la secuencia no es completa. De forma inmediata, el reconocimiento de las repeticiones de imágenes indica la inexistencia de un proceso de referencia ordenado cronológicamente. No obstante, las imágenes conservan una relación indicial directa con el acontecimiento de referencia: podríamos decir que las imágenes en términos generales remiten al desarrollo referencial en términos generales. Pero parecería que, en un sentido estricto, sólo las imágenes estarían ligadas a ese referente, si, como parece, el componente sonoro consistiría en una grabación preexistente, sobre la que se habría realizado además un trabajo de edición, de tal forma que las imágenes se habrían adaptado no a un continuo sonoro, sino a una construcción ${ }^{23}$. En ese sentido el trabajo sería diferente al de Horizontes perdidos, según la manera en que las imágenes se habrían adaptado entonces a un continuo sonoro, en ese caso ficticio pero tomado como un continuo impuesto dadas las características del material y los objetivos del trabajo.

La secuencia observada en Salut les cubains propone una serie de relaciones entre la imagen y el sonido, que podrían atenderse con un ánimo estructural. La elección de un sistema como el de la filmación de las fotografías plantea situaciones de interés particular cuando pretende aproximarse más a la representación de un desarrollo. De forma interesante, parecería que, frente al impacto inicial de la música y pese al carácter parcial del discurso discontinuo de las fotografías, es en estas últimas donde genuinamente residiría el corazón documental de la secuencia, cuya relación con el referente no destaca tanto en su vínculo indicial, sostenido por el contacto irrevocable de la imagen fotográfica, como en su logro semántico cuando en lo que pensamos es en la representación de un desarrollo completo.

\section{Referencias bibliográficas}

BASTIDE, B. (1991). Agnès Varda photographe ou l'appretissage du regard. En: M. ESTÈVE, (ed.). Agnès Varda. París: Lettres modernes Minard.

BASTIDE, B. (1994). Filmographie. Documents réunis par Bernard Bastide. En: A. VARDA. Varda par Agnès. París: Cahiers du cinéma.

BAZIN, A. (2004). ¿Qué es el cine? Madrid: Rialp.

CHIROLLET, J-C. (1983). Esthétique du photoroman. París: Edilig.

DREYER, S. (2009). Salut les cubains, une poétique du temoignage. En: A. FIANT, R. HAMERY, É. THOUVENEL (eds). Agnès Varda: le cinéma et au-delà. Rennes: Presses Universitaires de Rennes.

\footnotetext{
${ }^{23}$ Dentro de los límites de esta investigación no hemos localizado informaciones suficientemente específicas en torno a la música de esta película (sí, de forma general, en torno a la música en Varda) o, en concreto, de esta secuencia, cuya música hemos encontrado comparable a la grabación de Caricias cubanas del 10 de abril de 1957, incluida en la edición de cuatro discos compactos El legendario ídolo del pueblo cubano. Benny Moré y su Banda Gigante: grabaciones completas 1953-1960 (Moré, 2003).
} 
FIESCHI, J-A.; Ollier, C. (1965). La grâce laïque, entretien avec Agnès Varda. Cahiers du cinéma, 165, 42-51.

GITT, Robert (2001). Comentarios de la restauración (1998) por el crítico Charles Champlin y el experto de UCLA en restauración de películas Robert Gitt. En: F. Capra, (dir.). Horizontes perdidos (Lost Horizon). 128 min. Columbia Pictures, 1937. Madrid: Sony Pictures Home Entertainment. [DVD]

GRAR, Kawthar (2010). Le médium photographique : un modèle processuel dans l'écriture cinématographique d'Agnès Varda dans le film Salut les cubains. Université du Québec à Montréal, Memoria de Trabajo de Fin de Máster: http://www. archipel.uqam.ca/3391/1/M11491.pdf

HORAK, J-C. (1997). Making Images Move: Photographers and Avant-Garde Cinema. Washington, Londres: Smithsonian Institution.

INVERNICI, A. (2010). Filmografia. En: N. Falcinella, (ed.). Agnès Varda. Cinema senza tetto né legge. Recco-Genova: Le Mani.

KLINE, T. J. (ed.) (2014). Agnès Varda: Interviews. Jackson: University Press of Mississippi.

MEINI, T. (2003). El legendario ídolo del pueblo cubano. En: PUJOL, Jordi; MEINI, Tommy (eds.). Benny Moré. El legendario ídolo del pueblo cubano. Barcelona: Almendra Music. [Libreto de acompañamiento a MORÉ, Benny (2003). El legendario ídolo del pueblo cubano. Benny Moré y su Banda Gigante: grabaciones completas 1953-1960. Barcelona: Blue Moon]

MERINO, I. (2012). Subjectivitat i autorepresentació en el cinema d'Agnès Varda. Universitat Pompeu Fabra, Tesis Doctoral: http://www.tdx.cat/bitstream/handle/10803/109378/tim.pdf?sequence $=5$

ODIN, R. (1981). Le film de fiction menacé par la photographie et sauvé par la bande-son (à propos de la Jetée de Chris Marker). En: A. Gardies; F. Jost, D.Chateau, (dir.). Cinémas de la modernité: Films, théories : Colloque de Cerisy. París: Klincksieck.

VARDA, A. (1990). Antologia. A. Varda par Agnès V. (segmento: "Il proceso realizzativo"). En: S. Cortellazzo, M. Marangi (eds.). Agnès Varda. Turín: Edizioni di Torino.

VARDA, A. (1994). Varda par Agnès. París: Cahiers du cinéma. 


\section{Discografía}

MORÉ, B. (2003). El legendario ídolo del pueblo cubano. Benny Moré y su Banda Gigante: grabaciones completas 1953-1960. Barcelona: Blue Moon.

\section{Filmografía}

CAPRA, F. (1937). Horizontes perdidos (Lost Horizon).

MARKER, C. (1962). La jetée.

REICHENBACH, F. (1960). América insólita (L’Amérique insolite).

RUIZ, R. (1977). Colloque de chiens.

VARDA, A. (1954). La Pointe Courte.

VARDA, A. (1961a). Cleo de cinco a siete (Cléo de 5 à 7).

VARDA, A. (1961b). Les fiancés du Pont Mac Donald.

VARDA, A. (1963). Salut les cubains.

VARDA, A. (1981). Murs, murs.

VARDA, A. (1982). Ulysse.

VARDA, A. (1983). Une minute pour une image.

VARDA, A. (2004). Ydessa, les ours et etc. 